\title{
The Atomic Genetic Code
}

\section{Lutvo Kuriæ}

Independent Researcher, Bosnia and Herzegovina, 72290 Novi Travnik, Kalinska 7

Corresponding author: Independent Researcher, Bosnia and Herzegovina, 72290 Novi Travnik, Kalinska 7, Tel: 061763 917; E-mail: lutvokuric@yahoo.com

Received February 06, 2009; Accepted February 25, 2009; Published February 27, 2009

Citation: Lutvo Kuriæ (2009) The Atomic Genetic Code. J Comput Sci Syst Biol 2: 101-116. doi:10.4172/jcsb.1000022

Copyright: (C) 2009 Lutvo Kuriæ. This is an open-access article distributed under the terms of the Creative Commons Attribution License, which permits unrestricted use, distribution, and reproduction in any medium, provided the original author and source are credited.

\section{Abstract}

The modern science mainly treats the biochemical basis of sequencing in bio-macromolecules and processes in biochemistry. One can ask weather the language of biochemistry is the adequate scientific language to explain the phenomenon in that science. Is there maybe some other language, out of biochemistry, that determines how the biochemical processes will function and what the structure and organization of life systems will be? The research results provide some answers to these questions. They reveal to us that the process of sequencing in bio-macromolecules is conditioned and determined not only through biochemical, but also through cybernetic and information principles.

Keywords: Digital genetics; Genetics code; RNA code; Amino acids code; Evolution

\section{Methods}

The genetic code tables used by the modern science are characterized and determined by principles of biochemistry. However, if in those tables, instead of the UCAG nucleotides we put the number of atoms of those nucleotides, we will get the new tables of the genetic code characterized and determined by programmatic and information principles. Therefore, biochemistry can be explained through a phenomenon out of biochemistry. Particularly interesting results we will get when determining numeric values for the information content of atoms and molecules. We will then find out that those values express physical and chemical characteristics of molecules. For example: in a DNA molecule, the polynucleotide chains are connected through an exact cyber-information connections. In those molecules there are also mathematical matrixes of DNA, represented by the number of atoms of four ATCG bases. These matrixes determine the positioning of nucleotides in that molecule. With this, the biological particularities of DNA are determined. Similar mathematical matrixes determine the positioning of nucleotides in the RNA molecule. In the amino acid proteins, they are interconnected into the respective mathemati- cal chains. In those chains are also matrixes where particular mathematical principles apply, the principles that determine the positioning of each amino acid in the chain.

\section{Results}

The herewith discussed research results show that the process of sequencing in bio-macromolecules is conditioned and determined not only through biochemical, but also through cybernetic information principles.

We would particularly like to stress here that the genetic, as well as biochemical information in a broader sense of the word, is determined and characterized by very complex cybernetic and information principles. The constantans in those principles are: the number of atoms and molecules, atomic numbers, atomic weight, physical and chemical parameters, even and odd values, codes and analogue codes, standard deviations, frequencies, primary and secondary values, and many other things. How functioning of biochemistry is determined through cybernetic information principles, will be discussed further in this text. 
The Atomic Genetic Code (RNA)

$\mathrm{A}=15$ atoms; $\mathrm{U}=12$ atoms; $\mathrm{C}=13$ atoms; $\mathrm{G}=16$ atoms;

Number of atoms

\begin{tabular}{|c|c|c|c|c|c|c|c|c|c|c|c|c|}
\hline $\begin{array}{l}\text { UUU }=36 \\
\text { Phe }=23\end{array}$ & $\begin{array}{l}\text { UUC }=37 \\
\text { Phe }=23 \\
U C U=37\end{array}$ & $\begin{array}{l}\text { CUC }=38 \\
\text { Leu }=22 \\
\text { UCC }=38\end{array}$ & $\begin{array}{l}\text { UUA }=39 \\
\text { Leu }=22 \\
A U U=39\end{array}$ & $\begin{array}{l}\text { UUG }=40 \\
\text { Leu }=22 \\
\text { AUC }=40\end{array}$ & $\begin{array}{l}\text { CUG }=41 \\
\text { Leu }=22 \\
\text { UGC }=41\end{array}$ & $\begin{array}{c}\mathrm{CGC}=42 \\
\mathrm{Arg}=26 \\
\mathrm{AUA}=42\end{array}$ & $\begin{array}{l}\text { GAU }=43 \\
\text { Asp }=16 \\
A U G=43\end{array}$ & $\begin{array}{l}\mathrm{GAC}=44 \\
\mathrm{Asp}=16 \\
\mathrm{UGG}=44\end{array}$ & $\begin{array}{c}\mathrm{CGG}=45 \\
\mathrm{Arg}=26\end{array}$ & $\begin{array}{c}\mathrm{AGA}=46 \\
\mathrm{Arg}=26 \\
\mathrm{AAG}=46\end{array}$ & $\begin{aligned} A G G & =47 \\
A r g & =26 \\
G G A & =47\end{aligned}$ & $\begin{aligned} \text { GGG } & =48 \\
\text { Gly } & =10\end{aligned}$ \\
\hline & $\begin{array}{r}U C U=37 \\
\text { Ser }=14\end{array}$ & $\begin{array}{r}\text { UCC }=38 \\
\text { Ser }=14\end{array}$ & $\begin{array}{r}\text { AUU }=39 \\
\text { Ile }=22\end{array}$ & $\begin{aligned} \text { AUC } & =40 \\
\text { Ile } & =22\end{aligned}$ & 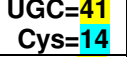 & $\begin{array}{r}\mathrm{AUA}=42 \\
\mathrm{Ile}=22\end{array}$ & $\begin{array}{r}\text { AUG }=43 \\
\text { Met }=20\end{array}$ & $\begin{array}{r}U G G=44 \\
\text { Trp }=27\end{array}$ & $\begin{aligned} \text { AAA } & =45 \\
\text { Lys } & =24\end{aligned}$ & $\begin{array}{l}\text { AAG }=46 \\
\text { Lys }=24\end{array}$ & $\begin{aligned} G G A & =47 \\
\text { Gly } & =10\end{aligned}$ & \\
\hline & $\begin{array}{c}\text { CUU }=37 \\
\text { Leu }=22\end{array}$ & $\begin{array}{r}\mathrm{CCU}=38 \\
\mathrm{PrO}=17\end{array}$ & $\begin{array}{c}C C C=39 \\
\text { Pro }=17\end{array}$ & $\begin{aligned} \text { CUA } & =40 \\
\text { Leu } & =22\end{aligned}$ & $\begin{array}{r}\text { CCA }=41 \\
\text { Pro }=17\end{array}$ & $\begin{array}{r}\mathrm{CCG}=42 \\
\operatorname{Pro}=17\end{array}$ & $\begin{aligned} \mathrm{AAC} & =43 \\
\mathrm{Asn} & =17\end{aligned}$ & $\begin{array}{r}\text { ACG }=44 \\
\mathrm{Thr}=17\end{array}$ & $\begin{aligned} \text { GGC } & =45 \\
\text { Gly } & =10\end{aligned}$ & $\begin{array}{c}\text { GAA }=46 \\
\text { Glu }=19\end{array}$ & $\begin{aligned} \text { GAG } & =47 \\
\text { Glu } & =19\end{aligned}$ & \\
\hline & & & $\begin{array}{r}\mathrm{UAU}=39 \\
\mathrm{Tyr}=24\end{array}$ & $\begin{aligned} \mathrm{GUU} & =40 \\
\mathrm{Val} & =19\end{aligned}$ & $\begin{array}{r}\text { GUC }=41 \\
\text { Val }=19\end{array}$ & $\begin{aligned} \mathrm{GCC} & =42 \\
\text { Ala } & =13\end{aligned}$ & $\begin{aligned} \text { GUA } & =43 \\
\mathrm{Val} & =19\end{aligned}$ & $\begin{aligned} \mathrm{GUG} & =44 \\
\mathrm{Val} & =19\end{aligned}$ & $\begin{aligned} \text { GCG } & =45 \\
\text { Ala } & =13\end{aligned}$ & & & \\
\hline & & & & $\begin{array}{r}\text { UCA }=40 \\
\text { Ser }=14\end{array}$ & $\begin{array}{r}\text { UCG }=41 \\
\text { Ser }=14\end{array}$ & $\begin{array}{l}\text { UAA }=42 \\
\text { STOP }\end{array}$ & $\begin{array}{r}\text { AGU }=43 \\
\text { Ser }=14\end{array}$ & $\begin{array}{r}\text { AGC }=44 \\
\text { Ser }=14\end{array}$ & & & & \\
\hline & & & & $\begin{aligned} \mathrm{ACU} & =40 \\
\mathrm{Thr} & =17\end{aligned}$ & $\begin{aligned} \mathrm{ACC} & =41 \\
\mathrm{Thr} & =17\end{aligned}$ & $\begin{aligned} \mathrm{AAU} & =42 \\
\mathrm{Asn} & =17\end{aligned}$ & $\begin{array}{r}\text { ACA }=43 \\
\text { Thr }=17\end{array}$ & $\begin{aligned} \text { GGU } & =44 \\
\text { Gly } & =10\end{aligned}$ & & & & \\
\hline & & & & $\begin{aligned} \mathrm{UAC} & =40 \\
\mathrm{Tyr} & =24\end{aligned}$ & $\begin{aligned} \mathrm{GCU} & =41 \\
\mathrm{Ala} & =13\end{aligned}$ & & $\begin{array}{l}\text { UAG }=43 \\
\text { STOP }\end{array}$ & $\begin{array}{r}\mathrm{GCA}=44 \\
\text { Ala }=13\end{array}$ & & & & \\
\hline & & & & $\begin{aligned} \mathrm{CAU} & =40 \\
\mathrm{His} & =20\end{aligned}$ & $\begin{array}{r}\text { CAC }=41 \\
\text { His }=20\end{array}$ & & $\begin{array}{r}\text { CAA }=43 \\
\text { Gln }=20\end{array}$ & $\begin{array}{r}\text { CAG }=44 \\
\text { Gln }=20\end{array}$ & & & & \\
\hline & & & & $\begin{aligned} \text { UGU } & =40 \\
\text { Cys } & =14\end{aligned}$ & $\begin{array}{c}C G U=41 \\
\mathrm{Arg}=26\end{array}$ & & $\begin{array}{l}\text { UGA }=43 \\
\text { STOP }\end{array}$ & $\begin{array}{c}C G A=44 \\
\mathrm{Arg}=26\end{array}$ & & & & \\
\hline
\end{tabular}

Number of atoms in triplets UCAG

\begin{tabular}{|c|c|c|c|c|c|c|c|c|c|c|c|c|}
\hline $\begin{array}{c}\text { UUU } \\
36\end{array}$ & $\begin{array}{c}\text { UUC } \\
37\end{array}$ & $\begin{array}{c}\text { CUC } \\
38\end{array}$ & $\begin{array}{c}\text { UUA } \\
39\end{array}$ & $\begin{array}{c}\text { UUG } \\
40\end{array}$ & $\begin{array}{c}\text { CUG } \\
41\end{array}$ & $\begin{array}{c}\text { CGC } \\
42\end{array}$ & $\begin{array}{c}\text { GAU } \\
43\end{array}$ & $\begin{array}{c}\text { GAC } \\
44\end{array}$ & $\begin{array}{c}\text { CGG } \\
45\end{array}$ & $\begin{array}{c}\text { AGA } \\
46\end{array}$ & $\begin{array}{c}\text { AGG } \\
47\end{array}$ & $\begin{array}{c}\text { GGG } \\
48\end{array}$ \\
\hline & $\begin{array}{c}\text { UCU } \\
37\end{array}$ & $\begin{array}{c}\text { UCC } \\
38\end{array}$ & $\begin{array}{c}\text { AUU } \\
39\end{array}$ & $\begin{array}{c}\text { AUC } \\
40\end{array}$ & $\begin{array}{c}\text { UGC } \\
41\end{array}$ & $\begin{array}{c}\text { AUA } \\
42\end{array}$ & $\begin{array}{c}\text { AUG } \\
43\end{array}$ & $\begin{array}{c}\text { UGG } \\
44\end{array}$ & $\begin{array}{c}\text { AAA } \\
45\end{array}$ & $\begin{array}{c}\text { AAG } \\
46\end{array}$ & $\begin{array}{c}\text { GGA } \\
47\end{array}$ & \\
\hline & $\begin{array}{c}\text { CUU } \\
37\end{array}$ & $\begin{array}{c}\text { CCU } \\
38\end{array}$ & $\begin{array}{c}\text { CCC } \\
39\end{array}$ & $\begin{array}{c}\text { CUA } \\
40\end{array}$ & $\begin{array}{c}\text { CCA } \\
41\end{array}$ & $\begin{array}{c}\text { CCG } \\
42\end{array}$ & $\begin{array}{c}\text { AAC } \\
43\end{array}$ & $\begin{array}{c}\text { ACG } \\
44\end{array}$ & $\begin{array}{c}\text { GGC } \\
45\end{array}$ & $\begin{array}{c}\text { GAA } \\
46\end{array}$ & $\begin{array}{c}\text { GAG } \\
47\end{array}$ & \\
\hline & & & $\begin{array}{c}\text { UAU } \\
39\end{array}$ & $\begin{array}{c}\text { GUU } \\
40\end{array}$ & $\begin{array}{c}\text { GUC } \\
41\end{array}$ & $\begin{array}{c}\text { GCC } \\
42\end{array}$ & $\begin{array}{c}\text { GUA } \\
43\end{array}$ & $\begin{array}{c}\text { GUG } \\
44\end{array}$ & $\begin{array}{c}\text { GCG } \\
45\end{array}$ & & & \\
\hline & & & & $\begin{array}{c}\text { UCA } \\
40\end{array}$ & $\begin{array}{c}\text { UCG } \\
41\end{array}$ & $\begin{array}{c}\text { UAA } \\
42\end{array}$ & $\begin{array}{c}\text { AGU } \\
43\end{array}$ & $\begin{array}{c}\text { AGC } \\
44\end{array}$ & & & & \\
\hline & & & & $\begin{array}{c}A C U \\
40\end{array}$ & $\begin{array}{c}\mathrm{ACC} \\
41\end{array}$ & $\begin{array}{c}\text { AAU } \\
42\end{array}$ & $\begin{array}{c}\text { ACA } \\
43\end{array}$ & $\begin{array}{c}\text { GGU } \\
44\end{array}$ & & & & \\
\hline & & & & $\begin{array}{c}\text { UAC } \\
40\end{array}$ & $\begin{array}{c}\text { GCU } \\
41\end{array}$ & & $\begin{array}{c}\text { UAG } \\
43\end{array}$ & $\begin{array}{c}\text { GCA } \\
44\end{array}$ & & & & \\
\hline & & & & $\begin{array}{c}\text { CAU } \\
40\end{array}$ & $\begin{array}{c}\text { CAC } \\
41\end{array}$ & & $\begin{array}{c}\text { CAA } \\
43\end{array}$ & $\begin{array}{c}\text { CAG } \\
44\end{array}$ & & & & \\
\hline & & & & $\begin{array}{c}\text { UGU } \\
40\end{array}$ & $\begin{array}{c}\text { CGU } \\
41\end{array}$ & & $\begin{array}{c}\text { UGA } \\
43\end{array}$ & $\begin{array}{c}\text { CGA } \\
44\end{array}$ & & & & \\
\hline
\end{tabular}

$$
.(36+48)=(37+47)=(38+46)=(39+45)=(40+44)=(41+43) \text { etc. }
$$

In fact, we discovered that the mathematical balance in the distribution of codons and amino acids in the genetic code is achieved.

\section{Mathematical Position of the Nucleotides in Codon}

The development of prediction methods based on digital theory is focused on the exploration of new digital formulas and algorithms. The genetic code is stored in DNA molecules as sequences of bases: adenine (A) which pairs with thymine (T), and cytosine $(\mathrm{C})$ which pairs with guanine $(\mathrm{G})$, The analog of DNA in a digital genetic algorithm is a number of atoms, atomic numbers, analog codes, etc.

At mathematical evolution of genetic processes, nucleotides TCAG are being transformed to codons UCAG and later to amino acids and various organic composition. 


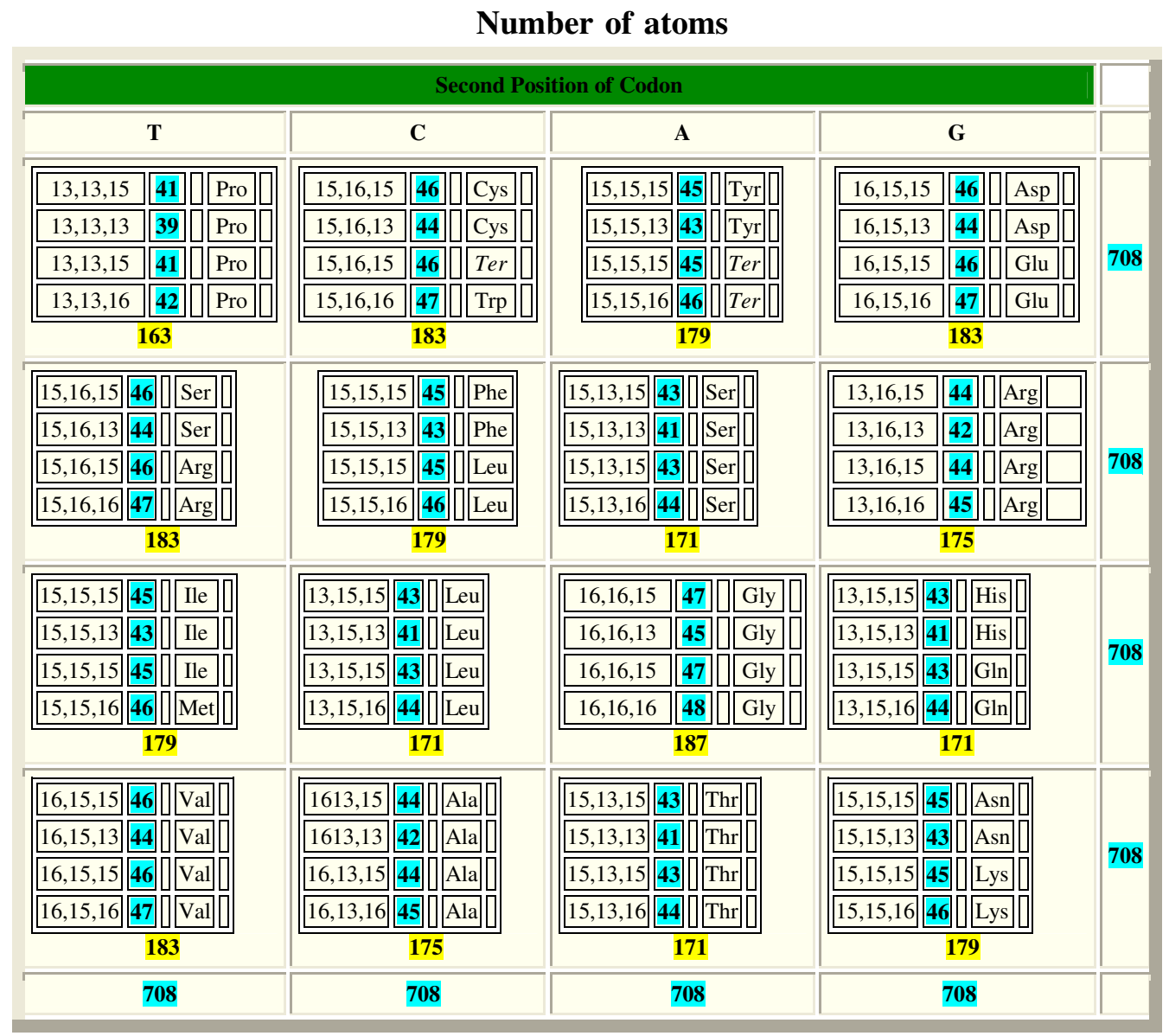

Diagonal D1 = 708; Diagonal D2 = 708;

The digital genetic code describe a genotype, which is translated into an organism a phenotype by the processes of cell division.

Mathematical evolution of genetic processes is manifested in different ways. Evolution of groups of atoms is especially interesting. Here are some examples

\section{Digital Codon Square}

A digital codon square of order $n$ is an arrangement of $n^{2}$ numbers, usually distinct integers, in a square, such that the $n$ numbers in all rows, all columns, and both diagonals sum to the same constant. A digital square contains the integers from 1 to $n^{2}$. The term "digital square" is also sometimes used to refer to any of various types of word square.

\section{Number of atoms}

\begin{tabular}{|c|c|c|c|c|}
\hline 163 & 183 & 179 & 183 & 708 \\
\hline 183 & 179 & 171 & 175 & 708 \\
\hline 179 & 171 & 187 & 171 & 708 \\
\hline 183 & 175 & 171 & 179 & 708 \\
\hline 708 & 708 & 708 & 708 & \\
\hline
\end{tabular}

$\mathrm{D} 1=(163+179+187+179)=708 ;$

$\mathrm{D} 2=(183+171+171+183)=708$; 
The constant sum in every row, column and diagonal is called the magic analogue constant or magic sum, $M$.

\begin{tabular}{|c|c|c|c|}
\hline 163 & 183 & 179 & 183 \\
\hline 183 & 179 & 171 & 175 \\
\hline 179 & 171 & 187 & 171 \\
\hline 183 & 175 & 171 & 179 \\
\hline
\end{tabular}

$(163+183+183+179)=708$;

$(179+183+171+175)=708$;

$(179+171+183+175)=708$;

$187+171+171+179)=708$;

\begin{tabular}{|l|l|l|l|}
\hline 163 & 183 & 179 & 183 \\
\hline 183 & 179 & 171 & 175 \\
\hline 179 & 171 & 187 & 171 \\
\hline 183 & 175 & 171 & 179 \\
\hline \multicolumn{4}{|c}{$\downarrow$} \\
\multicolumn{4}{|c}{708}
\end{tabular}

\begin{tabular}{|l|l|l|l|}
\hline 163 & 183 & 179 & 183 \\
\hline 183 & 179 & 171 & 175 \\
\hline 179 & 171 & 187 & 171 \\
\hline 183 & 175 & 171 & 179 \\
\hline \multicolumn{4}{|c}{$\downarrow$} \\
\multicolumn{3}{|c}{708}
\end{tabular}

etc.

\section{Analogue Atomic Genetic Code}

How could we adapt the program, ciberfnetic, and informational system to convey more information? Here's one way. This is an analogue code.

"Theoretically the ancient book of DNA could have been analogue. But, for the same reason as for our analogue armada beacons, any ancient book copied and recopied in analogue language would degrade to meaninglessness in very few scribe generations. Fortunately, human writing is digital, at least in the sense we care about here. And the same is true of the DNA books of ancestral wisdom that we carry around inside us. Genes are digital, and in the full sense not shared by nerves"(20).

\section{Correlation of the Code and Analogue Code}

The atomic and analogue genetic code is the set of rules by which information encoded in genetic material (DNA or RNA sequences) is translated into proteins (amino acid sequences) by living cells. Specifically, those codes defines a mapping between tri-nucleotide sequences called codons and amino acids; every triplet of nucleotides in a nucleic acid sequence specifies a single amino acid. Because the vast majority of genes are encoded with exactly the same code.

Those codes are universal. The same codons are assigned to the same amino acids and to the same START and STOP signals in the vast majority of genes in animals, plants, and microorganisms. 


\section{Analogue Code | | Code Code}

\section{Example:}

Analogue Code of the number 12 is number 21:

21 | | 12;

Analogue Code of the number 15 is number 51:

51 | | $15 ;$
etc.

At this stage of our research we replaced nucleotides from the Amino Acid Code Matrix with analogue numbers of the atoms in those nucleotides.

$$
\begin{gathered}
A=15 \text { atoms } ;=15 \text { atoms } ; C=13 \text { atoms } ;=16 \text { atoms } \\
A=51 ; T=51 ; C=31 ; G=61 ;
\end{gathered}
$$

\section{Analogue Codon Table}

\section{Mathematical position of the nucleotides in codon}

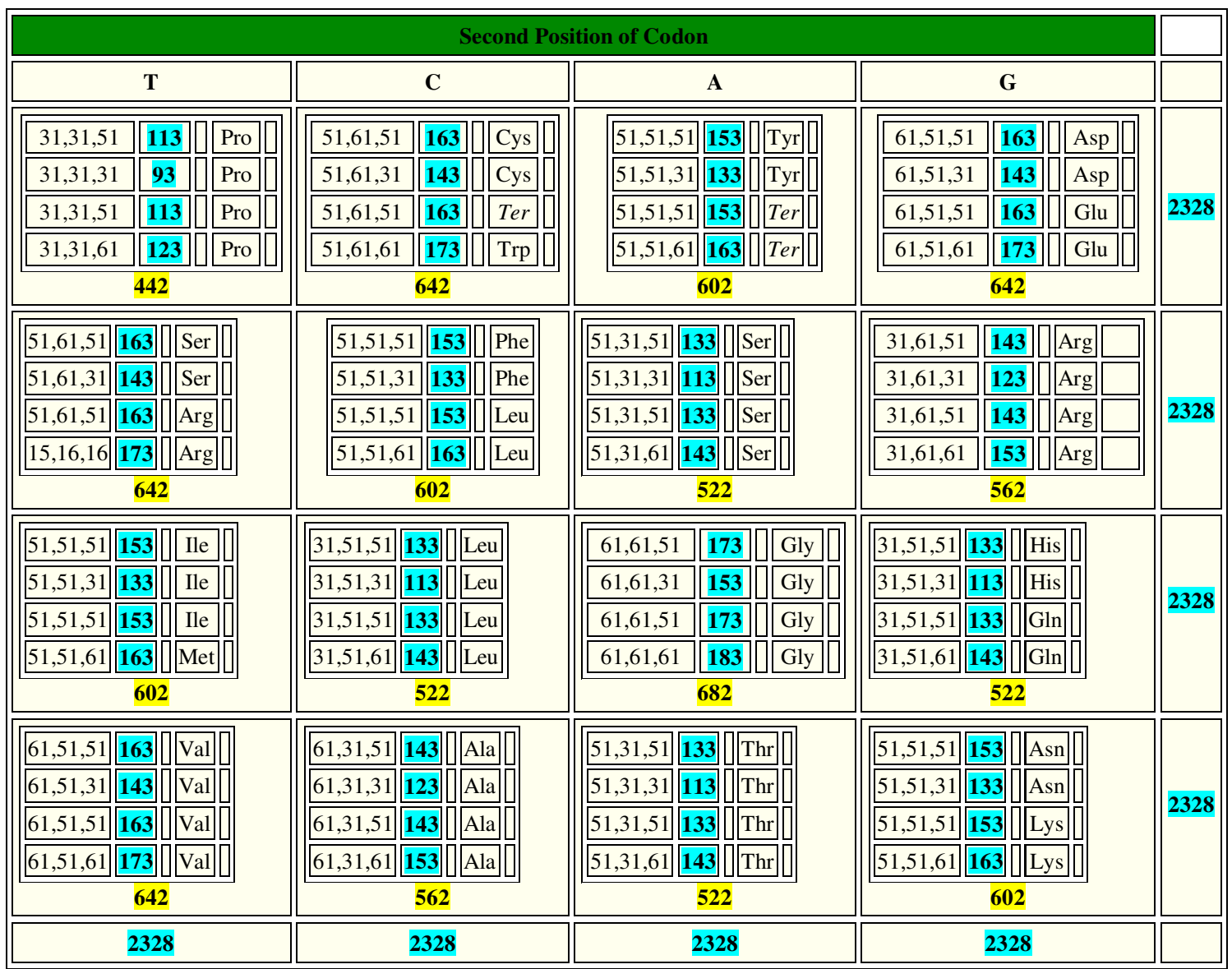

Diagonal D1 = 2328; Diagonal D2 = 2328;

Row $1=$ Column $1 ;$ Row $2=$ Column $2 ; \quad$ Row $3=$ Column $3 ;$ Row $4=$ Column 4 ;

\section{Analogue Codon Square}

A analogue codon square of order $n$ is an arrangement of $n^{2}$ numbers, usually distinct integers, in a square, such that the $n$ numbers in all rows, all columns, and both diagonals sum to the same constant. 
Research Article JCSB/Vol.2 January-February 2009

\begin{tabular}{|c|c|c|c|c|}
\hline $\mathbf{4 4 2}$ & $\mathbf{6 4 2}$ & $\mathbf{6 0 2}$ & $\mathbf{6 4 2}$ & $\mathbf{2 3 2 8}$ \\
\hline $\mathbf{6 4 2}$ & $\mathbf{6 0 2}$ & $\mathbf{5 2 2}$ & $\mathbf{5 6 2}$ & $\mathbf{2 3 2 8}$ \\
\hline $\mathbf{6 0 2}$ & $\mathbf{5 2 2}$ & $\mathbf{6 8 2}$ & $\mathbf{5 2 2}$ & $\mathbf{2 3 2 8}$ \\
\hline $\mathbf{6 4 2}$ & $\mathbf{5 6 2}$ & $\mathbf{5 2 2}$ & $\mathbf{6 0 2}$ & $\mathbf{2 3 2 8}$ \\
\hline $\mathbf{2 3 2 8}$ & $\mathbf{2 3 2 8}$ & $\mathbf{2 3 2 8}$ & $\mathbf{2 3 2 8}$ & \\
\hline
\end{tabular}

The constant sum in every row, column and diagonal is called the magic analogue constant or magic sum, $M=2328$;

\section{Correlation:}

\begin{tabular}{|l|l|l|l|}
\hline 442 & 642 & 602 & 642 \\
\hline 642 & 602 & 522 & 562 \\
\hline 602 & 522 & 682 & 522 \\
\hline 642 & 562 & 522 & 602 \\
\hline
\end{tabular}

$(442+642+642+602)=2328$;

$(602+642+522+562)=2328$;

etc.

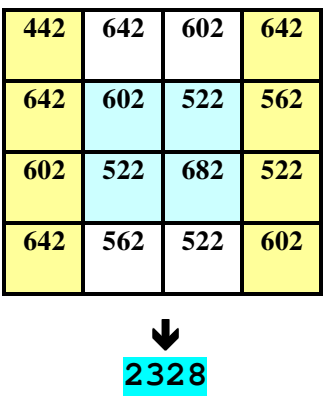

\begin{tabular}{|c|c|c|c|}
\hline 442 & 642 & 602 & 642 \\
\hline 642 & 602 & 522 & 562 \\
\hline 602 & 522 & 682 & 522 \\
\hline 642 & 562 & 522 & 602 \\
& \multicolumn{4}{|c|}{} \\
2328 \\
\end{tabular}

Determinants in Digital analogue Genetic Code

$\operatorname{DET}(4 \times 4)$

\begin{tabular}{|l|l|l|l|}
\hline 442 & 642 & 602 & 642 \\
\hline 642 & 602 & 522 & 562 \\
\hline 602 & 522 & 682 & 522 \\
\hline 642 & 562 & 522 & 602 \\
& \multicolumn{4}{|c}{$\downarrow$} \\
\multicolumn{4}{|c|}{2681856000}
\end{tabular}

$$
\mathbf{2 6 8 1 8 5 6 0 0 0}=(\mathbf{2 3 2 8}+\mathbf{2 3 2 8}+\mathbf{2 3 2 8} . . .,+2328) ;
$$

There is a mathematical balance within all of the phenomena in the analogue genetic code matrix.

Mathematical correlation of groups of nucleotides are a proof that genetic processes have evolved from one mathematical shape to another one. They are a proof that we can uncover some of hidden secrets in that science, with the help of mathematics. 


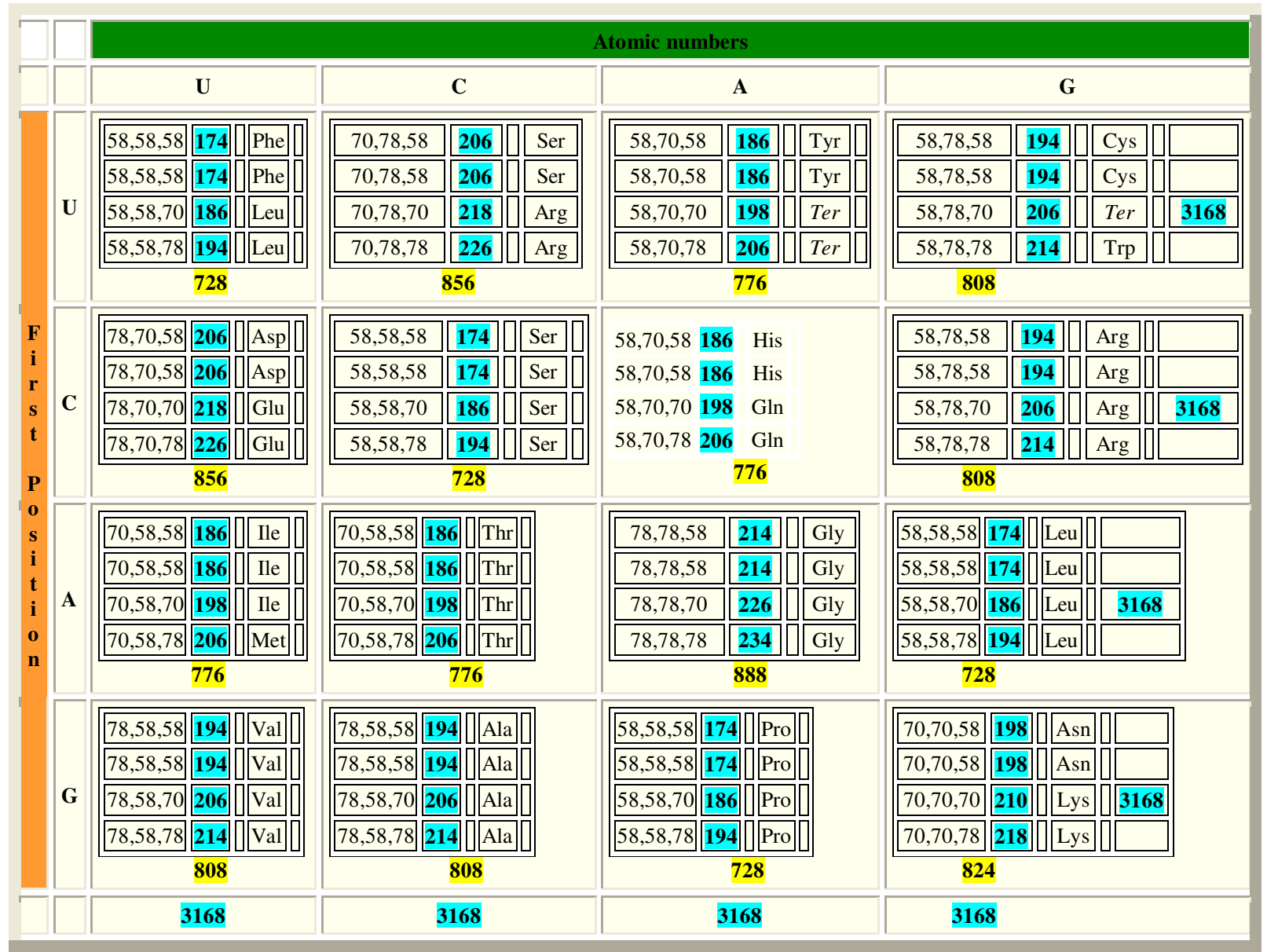

Diagonal D1 = 3168; Diagonal D2 = 3168;

The atomic genetic code describe a genotype, which is translated into an organism a phenotype by the processes of cell division.

Mathematical evolution of genetic processes is manifested in different ways. Evolution of groups of atoms is especially interesting. Here are some examples.

\section{Digital Codon Square}

A atomic codon square of order $n$ is an arrangement of $n^{2}$ numbers, usually distinct integers, in a square, such that the $n$ numbers in all rows, all columns, and both diagonals sum to the same constant. A digital square contains the integers from 1 to $n^{2}$. The term "digital square" is also sometimes used to refer to any of various types of word square.

Number of atoms

\begin{tabular}{|c|c|c|c|c|}
\hline 728 & 856 & 776 & 808 & 3168 \\
\hline 856 & 728 & 776 & 808 & 3168 \\
\hline 776 & 776 & $\mathbf{8 8 8}$ & 728 & 3168 \\
\hline 808 & 808 & 728 & 824 & 3168 \\
\hline 3168 & 3168 & 3168 & 3168 & \\
\hline
\end{tabular}

$$
\mathrm{D} 1=(728+856+776+808)=3168 ; \mathrm{D} 2=(808+776+776+808)=3168 ;
$$

The constant sum in every row, column and diagonal is called the magic analogue constant or magic sum, $M$ 
Research Article JCSB/Vol.2 January-February 2009

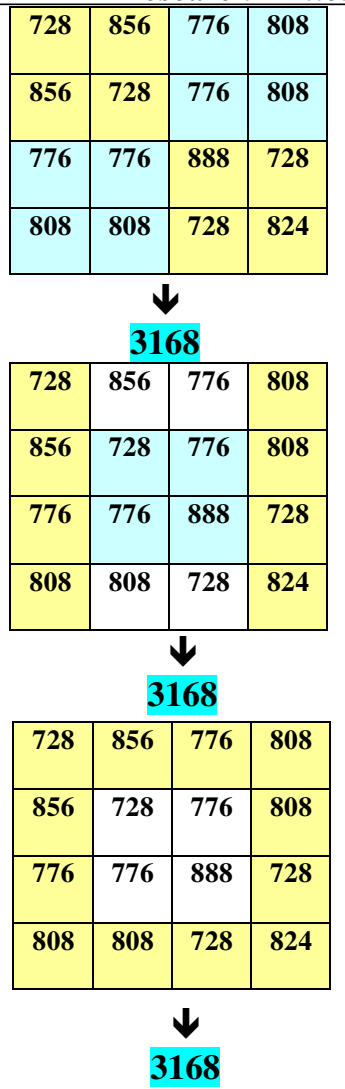

etc.

At this stage of our research we replaced nucleotides from the Amino Acid Code Matrix with analogue of the atomic numbers in those nucleotides.

\section{Analogue Codon Table}

\begin{tabular}{|c|c|c|c|c|c|c|c|c|c|c|c|c|c|c|c|c|c|}
\hline & & \multicolumn{16}{|c|}{ Atomic numbers } \\
\hline & & \multicolumn{3}{|c|}{$\mathbf{U}$} & \multicolumn{4}{|c|}{ C } & \multicolumn{4}{|c|}{$\mathbf{A}$} & \multicolumn{5}{|c|}{ G } \\
\hline & \multirow{5}{*}{$\mathbf{U}$} & $85,85,85$ & 255 & $\mathrm{Phe}$ & $07,87,85$ & & 79 & Ser & $85,07,85$ & 17 & 77 & \begin{tabular}{|l|} 
Tyr \\
\end{tabular} & $85,87,85$ & & 257 & Cys & \\
\hline & & $85,85,85$ & 255 & Phe & $07,87,85$ & & 179 & Ser & $85,07,85$ & 17 & 77 & Tyr & $85,87,85$ & & 257 & Cys & \\
\hline & & $85,85,07$ & 177 & Leu & $07,87,07$ & & 01 & Arg & $85,07,07$ & 9 & 9 & $\mathrm{Ter}$ & $85,87,07$ & & 179 & Ter & 3168 \\
\hline & & $\mid 85,85,87$ & 257 & Leu & $07,87,87$ & & 81 & Arg & $85,07,87$ & & 79 & Ter & $85,87,87$ & & 259 & Trp & \\
\hline & & \multicolumn{3}{|c|}{944} & \multicolumn{4}{|c|}{640} & \multicolumn{4}{|c|}{632} & \multicolumn{5}{|c|}{952} \\
\hline \multirow{4}{*}{$\begin{array}{l}\text { F } \\
\mathbf{i} \\
\mathbf{r} \\
\mathbf{s} \\
\mathbf{t}\end{array}$} & \multirow{5}{*}{ C } & $87,07,85$ & 179 & Asp & $85,85,85$ & & 55 & Ser & $85,07,85$ & 177 & His & & $85,87,85$ & & 257 & Arg & \\
\hline & & $\mid 87,07,85$ & $\mid 179$ & Asp & $85,85,85$ & & 55 & Ser & $\mid 85,07,85$ & 177 & His & & $85,87,85$ & & 257 & Arg & \\
\hline & & $\mid 87,07,07$ & 101 & Glu & $85,85,07$ & & 77 & Ser & $85,07,07$ & 99 & Gln & & $85,87,07$ & & 179 & Arg & 3168 \\
\hline & & $87,07,87$ & 181 & Glu & $85,85,87$ & & 57 & Ser & $85,07,87$ & 179 & Gln & & $85,87,87$ & & 259 & Arg & \\
\hline $\mathbf{P}$ & & \multicolumn{3}{|c|}{640} & \multicolumn{4}{|c|}{944} & \multicolumn{4}{|c|}{632} & \multicolumn{4}{|c|}{952} & \\
\hline s & \multirow{5}{*}{ A } & $\mid 07,85,85$ & 177 & Ile & $07,85,85$ & 177 & Thr & & $87,87,85$ & & 59 & Gly & $85,85,85$ & 255 & Leu & & \\
\hline 1 & & $\mid 07,85,85 \|$ & $\mid 177$ & Ile & $\mid 07,85,85$ & 177 & Thr & & $87,87,85$ & & 59 & Gly & $\mid 85,85,85$ & 255 & Leu & & \\
\hline i & & $\mid 07,85,07$ & 99 & Ile & $07,85,07$ & 99 & Thr & & $87,87,07$ & & 81 & Gly & $85,85,07$ & 177 & Leu & 3168 & \\
\hline $\mathbf{0}$ & & $07,85,87$ & 179 & Met & $07,85,87$ & 179 & Thr & & $87,87,87$ & 26 & 61 & Gly & $85,85,87$ & 257 & Leu & & \\
\hline "I & & \multicolumn{3}{|c|}{632} & \multicolumn{4}{|c|}{632} & \multicolumn{4}{|c|}{960} & \multicolumn{4}{|c|}{944} & \\
\hline & \multirow{5}{*}{ G } & $87,85,85$ & 257 & Val & $87,85,85$ & 257 & $\mathrm{Ala}$ & & $85,85,85$ & 255 & Pro & & $07,07,85$ & 99 & Ass & & \\
\hline & & $87,85,85$ & 257 & $\mathrm{Val}$ & $87,85,85$ & 257 & $\mathrm{Ala}$ & & $85,85,85$ & 255 & Pro & & $07,07,85$ & 99 & Ass & & \\
\hline & & $87,85,07$ & 179 & $\mathrm{Val}$ & $87,85,07$ & 179 & Ala & & $85,85,07$ & 177 & Pro & & $07,07,07$ & 21 & Ly: & 3168 & \\
\hline & & $87,85,87$ & 259 & Val & $87,85,87$ & 259 & Ala & & $85,85,87$ & 257 & Pro & & $\mid$\begin{tabular}{||c|}
$07,07,87$ \\
\end{tabular} & 101 & Ly: & & \\
\hline & & \multicolumn{3}{|c|}{952} & \multicolumn{4}{|c|}{952} & \multicolumn{4}{|c|}{944} & \multicolumn{4}{|c|}{320} & \\
\hline & & \multicolumn{3}{|c|}{3168} & \multicolumn{4}{|c|}{3168} & \multicolumn{4}{|c|}{3168} & 316 & & & & \\
\hline
\end{tabular}

ISSN:0974-7230 JCSB, an open access journal 
Diagonal D1 = 3168; Diagonal D2 = 3168;

Row 1 = Column 1; Row $2=$ Column 2; Row 3 = Column 3; Row 4 = Column 4;

\section{Analogue Codon Square}

A analogue codon square of order $n$ is an arrangement of $n^{2}$ numbers, usually distinct integers, in a square, such that the $n$ numbers in all rows, all columns, and both diagonals sum to the same constant.

\begin{tabular}{|c|c|c|c|c|}
\hline $\mathbf{9 4 4}$ & $\mathbf{6 4 0}$ & $\mathbf{6 3 2}$ & $\mathbf{9 5 2}$ & $\mathbf{3 1 6 8}$ \\
\hline $\mathbf{6 4 0}$ & $\mathbf{9 4 4}$ & $\mathbf{6 3 2}$ & $\mathbf{9 5 2}$ & $\mathbf{3 1 6 8}$ \\
\hline $\mathbf{6 3 2}$ & $\mathbf{6 3 2}$ & $\mathbf{9 6 0}$ & $\mathbf{9 4 4}$ & $\mathbf{3 1 6 8}$ \\
\hline $\mathbf{9 5 2}$ & $\mathbf{9 5 2}$ & $\mathbf{9 4 4}$ & $\mathbf{3 2 0}$ & $\mathbf{3 1 6 8}$ \\
\hline $\mathbf{3 1 6 8}$ & $\mathbf{3 1 6 8}$ & $\mathbf{3 1 6 8}$ & $\mathbf{3 1 6 8}$ & \\
\hline \\
D1 $=(944+944+960+320)=3168 ;$ \\
$\mathrm{D} 2=(952+632+632+952)=3168 ;$
\end{tabular}

The constant sum in every row, column and diagonal is called the magic analogue constant or magic sum, $M=3168$;

\section{Correlation:}

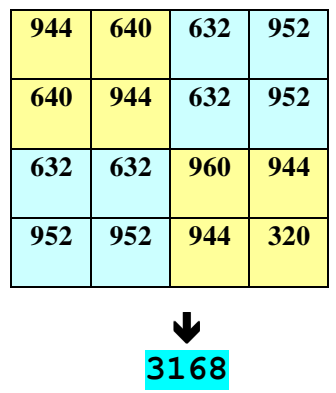

\begin{tabular}{|c|c|c|c|}
\hline 944 & 640 & 632 & 952 \\
\hline 640 & 944 & 632 & 952 \\
\hline 632 & 632 & 960 & 944 \\
\hline 952 & 952 & 944 & 320 \\
\hline
\end{tabular}

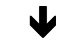

3168

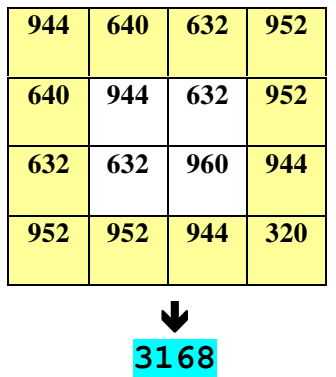

Determinants in Digital analogue Genetic Code

\begin{tabular}{|c|c|c|c|}
\multicolumn{5}{|c}{ DET $(4 \times 4)$} \\
\hline 944 & $\mathbf{6 4 0}$ & $\mathbf{6 3 2}$ & $\mathbf{9 5 2}$ \\
\hline $\mathbf{6 4 0}$ & $\mathbf{9 4 4}$ & $\mathbf{6 3 2}$ & $\mathbf{9 5 2}$ \\
\hline $\mathbf{6 3 2}$ & $\mathbf{6 3 2}$ & $\mathbf{9 6 0}$ & $\mathbf{9 4 4}$ \\
\hline 952 & $\mathbf{9 5 2}$ & $\mathbf{9 4 4}$ & $\mathbf{3 2 0}$ \\
\hline
\end{tabular}

197237145600

$197237145600=(3168+3168+3168 \ldots,+3168) ;$ 
There is a mathematical balance within all of the phenomena in the analogue genetic code matrix.

Mathematical correlation of groups of nucleotides are a proof that genetic processes have evolved from one mathematical shape to another one. They are a proof that we can uncover some of hidden secrets in that science, with the help of mathematics.

$$
\begin{aligned}
& \mathrm{C}=12,0111 ; \mathrm{H}=1,00797 ; \mathrm{N}=14,0067 ; \mathrm{O}=15,9994 ; \mathrm{S}=32,064 \text {; } \\
& A=135 ; U=112 ; C=111 ; G=151 ;
\end{aligned}
$$

\begin{tabular}{|l|l|l|l|l|l|l|}
\hline & C & H & N & O & S & \\
\hline A & 5 & 5 & 5 & 0 & 0 & 15 \\
\hline U & 4 & 4 & 2 & 2 & 0 & 12 \\
\hline C & 4 & 5 & 3 & 1 & 0 & 13 \\
\hline G & 5 & 5 & 5 & 1 & 0 & 16 \\
\hline
\end{tabular}

The Digital Genetic Code

At the first stage of our research we replaced nucleotides from the Genetic Code with atomic weight of those nucleotides.

\section{Mathematical Position of the Nucleotides in Codon3}

The development of prediction methods based on digital theory is focused on the exploration of new digital formulas and algorithms. The genetic code is stored in DNA molecules as sequences of bases: adenine (A) which pairs with thymine (T), and cytosine $(\mathrm{C})$ which pairs with guanine $(\mathrm{G})$, The analog of DNA in a digital genetic algorithm is a number of atoms, atomic numbers, analog codes, etc.

\begin{tabular}{|c|c|c|c|c|c|c|c|c|c|c|c|c|c|c|c|c|}
\hline & & \multicolumn{15}{|c|}{ Second Position of Codon } \\
\hline & & \multicolumn{3}{|c|}{$\mathbf{U}$} & \multicolumn{3}{|c|}{$\mathbf{C}$} & \multicolumn{4}{|c|}{$\mathbf{A}$} & \multicolumn{5}{|c|}{ G } \\
\hline & \multirow{4}{*}{$\psi$} & $112,111,112$ & 335 & Ser & $135,151,112$ & 398 & Ser & $111,135,112$ & 35 & & His & $112,151,112$ & 375 & & Yys & \\
\hline & & $112,111,111$ & 334 & Ser & $135,151,111$ & 397 & Ser & $111,135,111$ & 35 & & His & $112,151,111$ & 374 & & yys & \\
\hline & & $112,111,135$ & 358 & Ser & $135,151,135$ & 421 & Arg & $111,135,135$ & $\overline{38}$ & & Gln & $112,151,135$ & 398 & & \begin{tabular}{l|l}
$\operatorname{ler}$ & $\mathbf{6}$
\end{tabular} & 6108 \\
\hline & & $112,111,151$ & 374 & Ser & $135,151,151$ & 437 & Arg & $111,135,151$ & 39 & & Gln & $112,151,151$ & 14 & & $\mathrm{rpp}$ & \\
\hline $\mathbf{F}$ & & \multicolumn{3}{|c|}{1401} & \multicolumn{3}{|c|}{1653} & \multicolumn{4}{|c|}{1493} & \multicolumn{5}{|c|}{1561} \\
\hline \multirow{5}{*}{$\begin{array}{l}\mathbf{i} \\
\mathbf{r} \\
\mathrm{s} \\
\mathrm{t}\end{array}$} & \multirow{5}{*}{$\mathbf{C}$} & $151,135,112$ & 398 & Asp & $111,112,112$ & 335 & Leu & $\mid 135,111,112$ & 359 & \begin{tabular}{|l|l|}
$\mathrm{Thr}$ \\
\end{tabular} & & $\overline{151,112,11}$ & & 375 & & $\overline{\overline{\text { Val }}}$ \\
\hline & & $151,135,111$ & 397 & Asp & $111,112,111$ & 334 & Leu & $135,111,111$ & 358 & $\mathrm{Thr}$ & & $151,112,111$ & & 374 & & Val \\
\hline & & $151,135,135$ & 421 & Glu & $111,112,135$ & 358 & Leu & $135,111,135$ & 382 & $\mathrm{Thr}$ & & $151,112,135$ & & 398 & & Val \\
\hline & & $151,135,151$ & 437 & Glu & $111,112,151$ & 374 & Leu & $135,111,151$ & 398 & $\mathrm{Thr}$ & & $151,112,151$ & & 414 & & Val \\
\hline & & \multicolumn{3}{|c|}{1653} & \multicolumn{3}{|c|}{1401} & \multicolumn{4}{|c|}{1493} & \multicolumn{5}{|c|}{1561} \\
\hline $\mathbf{0}$ & \multirow{5}{*}{$\mathbf{A}$} & $112,135,112$ & 359 & Tyr & $135,112,112$ & 359 & Ile & $151,151,112$ & & 414 & Gly & $\mid 111,111,112$ & 334 & Pro & & \\
\hline s & & $112,135,111$ & 358 & Tyr & $135,112,111$ & 358 & Ile & $151,151,111$ & & 413 & Gly & $111,111,111$ & 333 & Pro & & \\
\hline t & & $112,135,135$ & 382 & $T e r$ & $135,112,135$ & 382 & Ile & $151,151,135$ & & 437 & $\overline{\mathrm{Gly}}$ & $111,111,135$ & 357 & Pro & 6108 & \\
\hline i & & $112,135,151$ & 398 & Ter & $135,112,151$ & 398 & Met & $151,151,151$ & & 453 & $\overline{\overline{\mathrm{Gly}}}$ & $\mid 111,111,151$ & 373 & Pro & & \\
\hline $\mathbf{0}$ & & \multicolumn{3}{|c|}{1497} & \multicolumn{3}{|c|}{1497} & \multicolumn{4}{|c|}{1717} & \multicolumn{5}{|c|}{1397} \\
\hline \multirow{6}{*}{$\mathbf{n}$} & \multirow{6}{*}{ G } & $111,151,112$ & 374 & \begin{tabular}{|l|l|}
$\operatorname{Arg}$ \\
\end{tabular} & $151,111,112$ & 374 & Ala & $112,112,112$ & 336 & Phe & & $135,135,112$ & 382 & Asn & & \\
\hline & & $111,151,111$ & 373 & Arg & 151,111,111 & 373 & Ala & $112,112,111$ & 335 & Phe & & $135,135,111$ & 381 & Asn & & \\
\hline & & $111,151,135$ & 397 & $\mathrm{Arg}$ & $151,111,135$ & 397 & Ala & $1112,112,135$ & 359 & Leu & & $135,135,135$ & 405 & Lys & 610 & 08 \\
\hline & & $111,151,151$ & 413 & $\operatorname{Arg}$ & $151,111,151$ & 413 & Ala & $112,112,151$ & 375 & Leu & & $135,135,151$ & 421 & Lys & & \\
\hline & & \multicolumn{3}{|c|}{1557} & \multicolumn{3}{|c|}{1557} & \multicolumn{4}{|c|}{1405} & \multicolumn{5}{|c|}{1589} \\
\hline & & \multicolumn{3}{|c|}{6108} & \multicolumn{3}{|c|}{6108} & & 6108 & & & & 108 & & & \\
\hline
\end{tabular}

At mathematical evolution of genetic processes, nucleotides TCAG are being transformed to codons UCAG and later to amino acids and various organic composition.

Diagonal D1 = 6108; Diagonal D2 = 6108 
The atomic genetic code describe a genotype, which is translated into an organism a phenotype by the processes of cell division.

Mathematical evolution of genetic processes is manifested in different ways. Evolution of groups of atoms is especially interesting. Here are some examples.

\section{Atomic Codon Square}

A atomic codon square of order $n$ is an arrangement of $n^{2}$ numbers, usually distinct integers, in a square, such that the $n$ numbers in all rows, all columns, and both diagonals sum to the same constant. A digital square contains the integers from 1 to $n^{2}$. The term "digital square" is also sometimes used to refer to any of various types of word square.

\begin{tabular}{|c|c|c|c|c|}
\multicolumn{6}{|c|}{ Number of atoms } \\
\hline 1401 & 1653 & 1493 & 1561 & \\
\hline 1653 & 1401 & 1493 & 1561 & \\
\hline 1497 & 1497 & 1717 & 1397 & \\
\hline 1557 & 1557 & 1405 & 1589 & \\
\hline 6108 & 6108 & 6108 & 6108 & \\
\hline
\end{tabular}

$$
\mathrm{D} 1=(1401+1401+1717+1589)=6108 ; \mathrm{D} 2=(1561+1493+1497+1557)=6108
$$

The constant sum in every row, column and diagonal is called the magic analogue constant or magic sum, $M$.

\begin{tabular}{|l|l|l|l|}
\hline 1401 & 1653 & 1493 & 1561 \\
\hline 1653 & 1401 & 1493 & 1561 \\
\hline 1497 & 1497 & 1717 & 1397 \\
\hline 1557 & 1557 & 1405 & 1589 \\
\hline \multicolumn{4}{|c|}{$\downarrow$} \\
6108
\end{tabular}

\begin{tabular}{|l|l|l|l|}
\hline 1401 & 1653 & 1493 & 1561 \\
\hline 1653 & 1401 & 1493 & 1561 \\
\hline 1497 & 1497 & 1717 & 1397 \\
\hline 1557 & 1557 & 1405 & 1589 \\
\hline \multicolumn{4}{|c|}{$\downarrow$} \\
6108
\end{tabular}

\begin{tabular}{|l|l|l|l|}
\hline 1401 & 1653 & 1493 & 1561 \\
\hline 1653 & 1401 & 1493 & 1561 \\
\hline 1497 & 1497 & 1717 & 1397 \\
\hline 1557 & 1557 & 1405 & 1589 \\
\hline \multicolumn{4}{|c|}{$\downarrow$} \\
6108
\end{tabular}

etc.

At this stage of our research we replaced nucleotides from the Amino Acid Code Matrix with analogue of the atomic weight in those nucleotides. 


$$
\begin{aligned}
& A=135 ; U=112 ; C=111 ; G=151 ; \\
& A=531 ; U=211 ; C=111 ; G=151 ;
\end{aligned}
$$

\section{Analogue Codon Table}

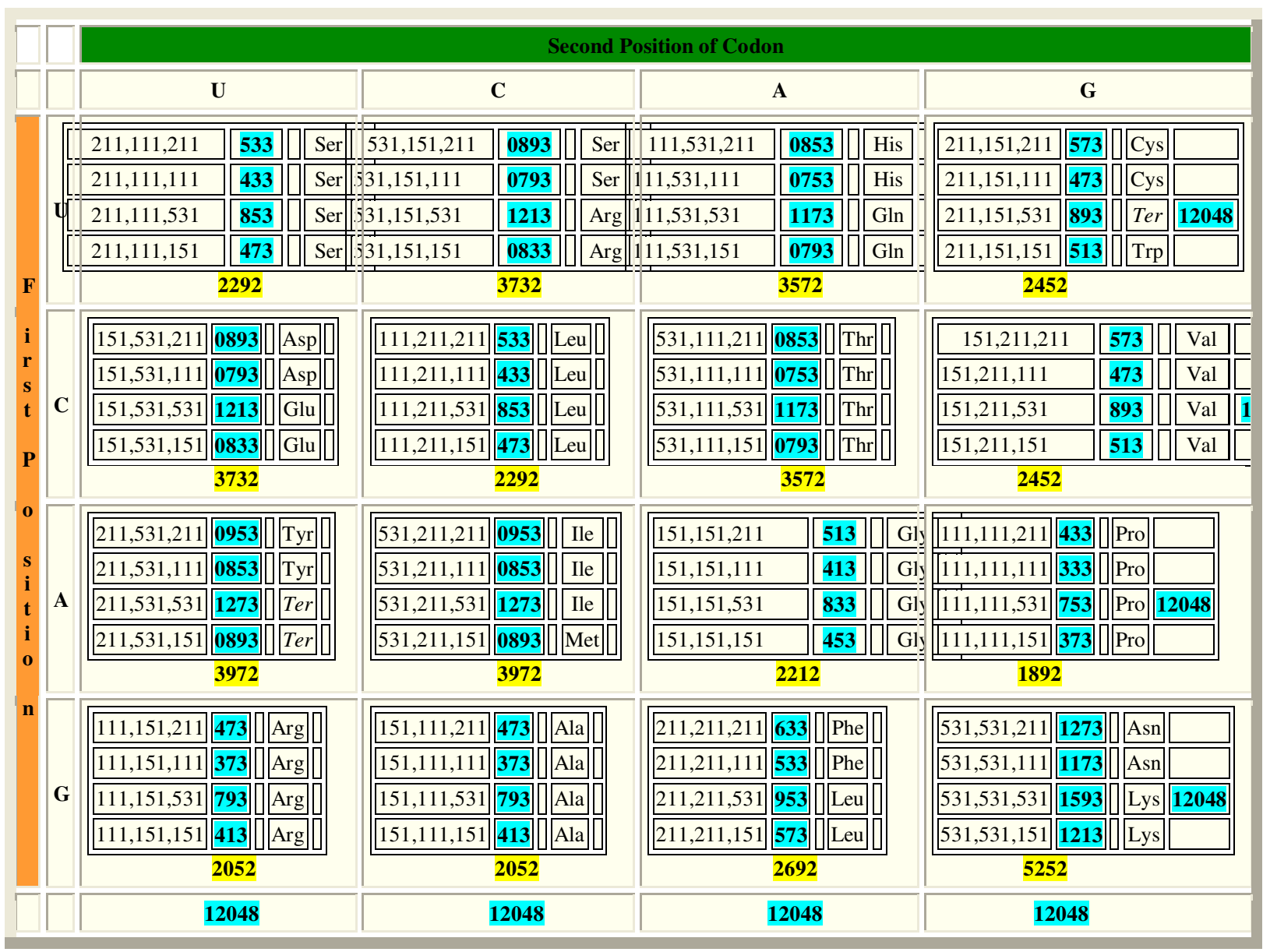

Diagonal D1 = 3168; Diagonal D2 = 3168;

\section{Analogue Codon Square}

A analogue codon square of order $n$ is an arrangement of $n^{2}$ numbers, usually distinct integers, in a square, such that the $n$ numbers in all rows, all columns, and both diagonals sum to the same constant.

\begin{tabular}{|r|r|r|r|r|}
\hline 2292 & 3732 & 3572 & 2452 & 12048 \\
\hline 3732 & 2292 & 3572 & 2452 & 12048 \\
\hline 3972 & 3972 & 2212 & 1892 & 12048 \\
\hline 2052 & 2052 & 2692 & 5252 & 12048 \\
\hline 12048 & 12048 & 12048 & 12048 & \\
\hline
\end{tabular}

$$
\text { D1 }=12048 ; \text { D2 = } 12048
$$

The constant sum in every row, column and diagonal is called the magic analogue constant or magic sum, $M=12048$;

Correlation:

\begin{tabular}{|l|l|l|l|}
\hline 2292 & 3732 & 3572 & 2452 \\
\hline 3732 & 2292 & 3572 & 2452 \\
\hline 3972 & 3972 & 2212 & 1892 \\
\hline & & & \\
2052 & 2052 & 2692 & 5252 \\
\hline \multicolumn{4}{|c|}{12048}
\end{tabular}

ISSN:0974-7230 JCSB, an open access journal 


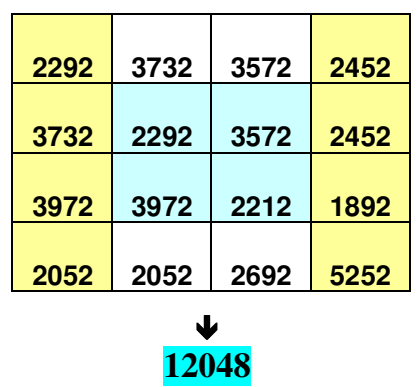

\begin{tabular}{|l|l|l|l|}
\hline 2292 & 3732 & 3572 & 2452 \\
\hline 3732 & 2292 & 3572 & 2452 \\
\hline 3972 & 3972 & 2212 & 1892 \\
\hline 2052 & 2052 & 2692 & 5252 \\
\hline \multicolumn{4}{|c|}{12048} \\
etc.
\end{tabular}

\section{Determinsants in Digital Analogue Genetic Code}

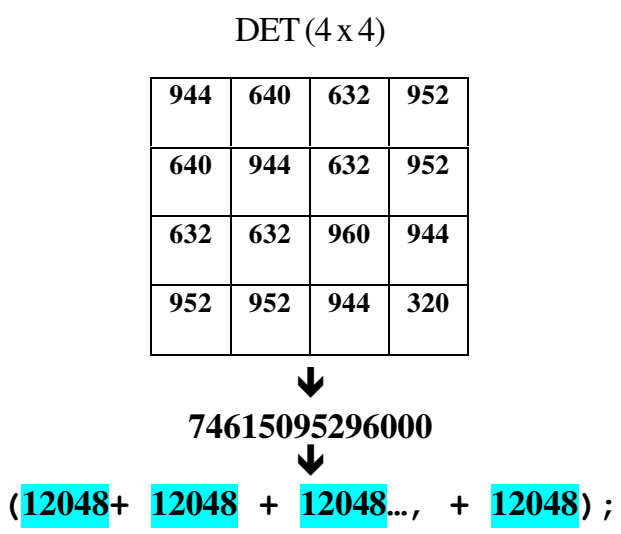

There is a mathematical balance within all of the phenomena in the analogue genetic code matrix.

Mathematical correlation of groups of nucleotides are a proof that genetic processes have evolved from one mathematical shape to another one. They are a proof that we can uncover some of hidden secrets in that science, with the help of mathematics.

It is obvious that digital matrix of amino acid code evolved from digital matrix of nucleotide code.

Mathematical correlation of groups of nucleotides are a proof that genetic processes have evolved from one mathematical shape to another one. They are a proof that we can uncover some of hidden secrets in that science, with the help of mathematics.

\section{Perspectives}

\section{About Importance of the Proposal}

Development of science in following period will be based on contemporary digital technology. To conquer new technology it would be far more efficient to use method of reverse engineering for comprehension of phenomen in ge- netics. We'll give a brief description of that method.

The genetic code tables used by the modern science are characterized and determined by principles of biochemistry. However, if in those tables, instead of the UCAG nucleotides we put the number of atoms of those nucleotides, we will get the new tables of the genetic code characterized and determined by programmatic and information principles. 
Therefore, biochemistry can be explained through a phenomenon out of biochemistry.

Particularly interesting results we will get when determining numeric values for the information content of atoms and molecules. We will then find out that those values express physical and chemical characteristics of molecules. For example: in a DNA molecule, the polynucleotide chains are connected through an exact cyber-information connections. In those molecules there are also mathematical matrixes of DNA, represented by the number of atoms of four ATCG bases. These matrixes determine the positioning of nucleotides in that molecule. With this, the biological particularities of DNA are determined. Similar mathematical matrixes determine the positioning of nucleotides in the RNA molecule. In the amino acid proteins, they are interconnected into the respective mathematical chains. In those chains are also matrixes where particular mathematical principles apply, the principles that determine the positioning of each amino acid in the chain. Therefore, the herewith discussed research results show that the process of sequencing in bio-macromolecules is conditioned and determined not only through biochemical, but also through cybernetic information principles. The hypothesis here is that the processes in an organism occur only when certain mathematical conditions are met, i.e. when there is a certain mathematical correlation between parameters in those processes. That correlation is expressed by the respective methodology.

We would particularly like to stress here that the genetic, as well as biochemical information in a broader sense of the word, is determined and characterized by very complex cybernetic and information principles. The constantans in those principles are: the number of atoms and molecules, atomic numbers, atomic weight, physical and chemical parameters, even and odd values, codes and analogue codes, standard deviations, frequencies, primary and secondary values, and many other things.

\section{Where it Might be Useful}

In view of this, our findings might have a series of impacts to the aforementioned work. We are devoted to provide a digital code for each of 20 native amino acids. These digital codes should more complete and better reflect the essence of each of the 20 amino acids. Therefore, it might stimulate a series of future work by using the author's digital codes to formulate the pseudo amino acid composition
Research Article JCSB/Vol.2 January-February 2009

for predicting protein structure class, subcellular location, membrane protein type, enzyme family class, GPCR type, protease type, protein-protein interaction, metabolic pathways, protein quaternary structure, and other protein attributes.

We can expect that this discovery will significantly speed up the research of mutational genesis of humans, molecular etymology, in applied biology and genetic engineering, and also it will provide discoveries in new medicines and methods of medicinal treatments.

\section{Future Steps Required}

1.Establish scientific-research project team for development of advanced technologies in genetics, medicine and biochemistry.

2.Project team should make concrete program of scientific-research work, where they should define goals of research, indispensable facilities for implementation of project, project duration, budget, and other conditions.

3. Define rights and duties of all participants in implementation of project.

4. To implement project defined by project documentation.

\section{Research in the Field of Fundamental Sciences}

1. Decode matrix of amino acid code and on the experimental way prove that the matrix really exists. And after that, use that matrix to conquer top technologies in the field of genetics.

2. Decode matrix of nucleotide code and digital codes which connect that matrix with matrix of amino acid code. And use that matrix to conquer top technologies in the field of biochemistry.

3. Decode matrix code in Tables of periodic system of chemical elements, and use that matrix to conquer top technologies in the field of chemistry.

4. Decode matrix code in the nature, and use that matrix to conquer top technologies in the field of all natural sciences.

5. Decode matrix code of chromosomes in human body.

6. With the help of above mentioned matrixes, decode map of human DNA.

7. Decode matrix code of processes in the field of nuclear physics.

8. Decode insulin matrix code, as well as all other codes from the field of biochemistry. 
9. Other research (Matrix code in Pascal's triangle, Matrix code in astronomy, Matrix code in theoretical physics, determinism, etc.).

\section{Paragraph of Limitations}

1. Confirm that the manuscript has been submitted solely to this journal and is not published, in press, or submitted elsewhere.

2. Confirm that all the research meets the ethical guidelines, including adherence to the legal requirements of the study country.

3. Confirm that you have completed and sent a Copyright Transfer Agreement (CTA) to the Editorial Office.

\section{The Obtained Results}

The obtained results are valid. In this manuscript, we proposed the universal genetic code. Mathematics could confirm this fact with $100 \%$ scientific accuracy. For example, Table mathematical position of the nucleotides in codon, Digital codon square, Analogue atomic genetic code, Correlation of the code and analogue code Analogue codon table, Analogue codon square, Determinsants in Digital analogue Genetic Code, Determinsants in Digital analogue Genetic Code, Atomic weight Atomic codon square, etc. This mathematic system represents that very universal formula of the genetic code which $100 \%$ scientific accuracy. was looking for.

\section{Conclusion}

It is a rewarding work to translate the biochemical language of amino acids into a digital language because it may be very useful for developing new methods for predicting protein sub cellular localization, membrane protein type, protein structure secondary prediction or any other protein attributes.

This is because ever since the concept of Chou's pseudo amino acid composition was proposed many efforts have been made trying to use various digital numbers to represent the 20 native amino acids in order to better reflect the sequence-order effects through the vehicle of pseudo amino acid composition. Some investigators used complexity measure factor some used the values derived from the cellular automata, some used hydrophobic and/or hydrophilic values, some were through Fourier transform, and some used the physicochemical distance.
Now, it is going to be possible to use the completely new strategy of research in genetics. However, observation of all these relations which are the outcome of the periodic law (actually, of the law of binary coding) is necessary, because it can be of great importance for decoding conformational forms and stereo-chemical and digital structure of proteins.

\section{Referecnces}

1. Chou KC (1995) A novel approach to predicting protein structural classes in a (20-1)-D amino acid composition space, Proteins: Struct. Funct Gen 21: 319-344. » Pubmed " Google Scholar

2. Chou KC (2000) Review: Prediction of protein structural classes and subcellular locations, Curr Prot Peptide Sci 1: 171-208. » CrossRef » Pubmed » Google Scholar

3. Chou KC (2000) Prediction of protein subcellular locations by incorporating quasi-sequence-order effect, Biocheml Biophys. Res Commun 278: 477-483.» Pubmed » Google Scholar

4. Chou KC (2001) Prediction of protein cellular attributes using pseudo amino acid composition, Proteins: Struct. Funct Genet 43: 246-255. » CrossRef » Pubmed » Google Scholar

5. Chou KC (2002) In Weinrer Pw, Lu Q (eds) Gene Cloningand Expression technologies, Eaton Publishing. Westborough, MA.

6. Chou KC (2005) Using amphiphilic pseudo amino acid composition to predict enzyme subfamily classes. Bioinformatics 21: 10-19.» CrossRef » Pubmed » Google Scholar

7. Chou KC (2005) Prediction of G-protein-coupled receptor classes, Journal of Proteome Research 4: 1413-1418. » Pubmed

8. Chou KC, Cai YD (2003) Predicting protein quaternary structure by pseudo amino acid composition. Proteins: Struct Funct Genet 53: 282-289. » Pubmed » Google Scholar

9. Chou KC, Cai YD (2004) Predicting enzyme family class in a hybridization space Protein Sci 13:2857-2863. » CrossRef " Pubmed » Google Scholar

10. Chou KC, Cai YD (2005) Prediction of membrane protein types by incorporating amphipathic effects. J Chem Inform and Model 45: 407-413. » Pubmed » Google Scholar

11. Chou KC, Cai YD (2006) Prediction of protease types in a hybridization space. Biochem Biophys Res Comm 339: 1015-1020.» CrossRef » Pubmed » Google Scholar 
Journal of Computer Science \& Systems Biology - Open Access

12. Chou KC, Cai YD (2006) Predicting protein-protein interactions from sequences in a hybridization space. $\mathrm{J}$ Proteome Res 5: 316-322.» Pubmed » Google Scholar

13. Chou KC, Cai YD (2006) Zhong WZ, Predicting networking couples for metabolic pathways of Arabidopsis. EXCLI J 5: 55-65.

14. Chou KC, Elord DW (1999) Protein subcellular location prediction. Protein Eng 12: 107-118. "CrossRef » Pubmed " Google Scholar

15. Chou KC, Elord DW Prediction of membrane protein types and subcellular locations. Proteins Struct Funct Genet 34: 137-153. " Pubmed " Google Scholar

16. Chou KC, Elrod DW (2002) Bioinformatical analysis of G-protein- coupled receptors. J Proteome Res 1: 429433. " Pubmed » Google Scholar

17. Chou KC, Elrod DW Prediction of enzyme family classes. J Proteome Res 2: 183-190.» Pubmed » Google Scholar

18. Chou KC, Zhang CT (1994) Predicting protein folding types by distance functions that make allowances for amino acid interactions. J Biol Chem 269: 22014-22020. » CrossRef » Pubmed » Google Scholar

19. Chou KC, Zhang CT (1995) Review: Prediction of protein structural classes. Critical Reviews Biochem Mol Biol 30: 275-349. » CrossRef » Pubmed » Google Scholar

20. Kuriæ L (2007) The digital language of amino acids. Amino Acids January 25. » Pubmed » Google Scholar

21. Kuriæ L (1986) Mesure complexe des caracteristiques dynamiques de series temporelles "Journal de la Societe de statistique de Paris"- tome 127, No 2.1986.

22. Wang M, Yang J, Liu GP, Xu ZJ, Chou KC (2004) Weighted-support vector machines for predicting membrane protein types based on pseudo amino acid compo-
Research Article JCSB/Vol.2 January-February 2009

sition. Protein Eng Des Select 17: 509-516. " CrossRef

" Pubmed » Google Scholar

23. Wang M, Yang J, Liu GP, Xu ZJ, Chou KC (2005) SLLE for predicting membrane protein types. $\mathrm{J}$ Theor Biol 232: 7-15. » CrossRef » Pubmed » Google Scholar

24. Wang SQ, Yang J, Chou KC (2006) Using stacked generalization to predict membrane protein types based on pseudo amino acid composition. J Theor Biology doi:10.1016/j.jtbi.1005.1006. » CrossRef » Pubmed » Google Scholar

25. Xiao X, Shao S, Ding Y, Huang Z, Chen X, et al. (2005) An Application of Gene Comparative Image for Predicting the Effect on Replication Ratio by HBV Virus gene missense mutation. J Theor Biol 235: 555-565. » CrossRef " Pubmed " Google Scholar

26. Xiao X, Shao S, Ding Y, Huang Z, Huang Y, et al. (2005) Using complexity measure factor to predict protein subcellular location. Amino Acids 28:57-61." CrossRef » Pubmed » Google Scholar

27. Xiao X, Shao S, Ding Y, Huang Z, Chen X, et al. (2005) Using cellular automata to generate Image representation for biological sequences. Amino Acids 28: 29-35. » Pubmed » Google Scholar

28. Xiao X, Shao SH, Huang ZD, Chou KC (2006) Using pseudo amino acid composition to predict protein structural classes: approached with complexity measure factor. J Comput Chem 27: 478-482.» CrossRef » Pubmed » Google Scholar

29. Xiao X, Shao SH, Ding YS, Huang ZD, Chou KC (2006) Using cellular automata images and pseudo amino acid composition to predict protein sub-cellular location. Amino Acids 30: 49-54.» Pubmed » Google Scholar

30. Zhang SW, Pan Q, Zhang HC, Shao ZC, Shi JY (2006) Prediction protein homo oligomer types by pseudo amino acid composition: Approached with an improved feature extraction and naive Bayes feature fusion. Amino Acids 30: 461-468.» Pubmed » Google Scholar 